Short communication

\title{
Temporal asymmetries in the feeding patterns along the tidal cycle in two sympatric littoral blennies
}

\author{
C. Faria*, V.C. Almada \\ Unidade de Investigação em Eco-Etologia, Instituto Superior de Psicologia Aplicada, R. Jardim do Tabaco 34, P-1149-041 Lisboa, Portugal
}

\section{A R T I C L E I N F O}

\section{Article history:}

Received 17 February 2008

Accepted 9 May 2008

Available online 18 May 2008

\section{Keywords:}

Lipophrys pholis

Coryphoblennius galerita

rocky shore

feeding activity

tidal rhythms

microhabitat shifts

\begin{abstract}
A B S T R A C T
The temporal patterns of feeding activity of Lipophrys pholis and Coryphoblennius galerita were studied by snorkelling dives during high-waters. The feeding activity was especially intense during the rising-tide when compared to the ebbing-tide. The relative abundances of $C$. galerita and small $L$. pholis observed on rock-walls were higher during the rising- and high-tide. However, L. pholis larger than 7-8 cm showed higher relative abundance on rock-walls during the ebbing phase, apparently because they move up and down with the tide, and many individuals were in their downward movements as the tide ebbs. It is hypothesized that the asymmetry in feeding pattern observed in both species reflects a trade off between two conflicting needs, maximizing feeding time and reaching their low-tide shelters in time, avoiding the risk of getting stranded in unsuitable locations.
\end{abstract}

(c) 2008 Elsevier Ltd. All rights reserved.

\section{Introduction}

A salient feature of the animals that colonize the intertidal habitat is the prevalence on a wide spectrum of taxa of periodical oscillations, both physiological and behavioural, that are typically driven by internal clocks, and are entrained by external cues that keep them nearly in phase with the tidal cycle (e.g. Williams and Naylor, 1969; Gibson, 1967, 1970, 1973, 1982; Northcott et al., 1990; Northcott, 1991). These "tidal rhythms" seem to enable the organisms to track and anticipate physical, chemical and biotic oscillations that the tide imposes on intertidal organisms (for a review, see Gibson, 1999). Bhikajee and Green (2002) give an interesting extreme example of an amphibious blenny that remains almost constantly emersed, moving up and down with the tide, above the water level.

There is still very limited information on the interspecific variation of tidal rhythms that rocky intertidal fish of the same community may display. This is an important gap in our knowledge of the rocky intertidal fish communities. In a given assemblage fish typically vary in size, diet, preferred low-tide shelter and spawning site. They are likely to differ also in the extent of their high-tide excursions away from shelters and in the spatial and temporal patterns of exploitation of the available resources.

In Western Europe blennies, namely Lipophrys pholis and Coryphoblennius galerita are major components of the resident icthyofauna of the rocky intertidal habitats (e.g. Gibson, 1972;

\footnotetext{
* Corresponding author

E-mail address: cfaria@ispa.pt (C. Faria).
}

Milton, 1983; Faria and Almada, 1999, 2001), and there have been attempts to access possible resource partitioning among them (e.g. Milton, 1983; O'Farrell and Fives, 1990; Faria and Almada, 2001). This resource partitioning may be expressed in trophic differences; however, it seems also to be expressed through differences in ontogeny: L. pholis grows faster and reaches a larger size than C. galerita, which leads the two species to use different types of shelter and prey (Milton, 1983; Faria and Almada, 2001; Monteiro et al., 2005). Indeed, $L$. pholis attains a much larger adult size than C. galerita (Zander, 1986). When they are about 1 year old, L. pholis reach the upper size of adult $C$. galerita (Faria et al., 1996). At this stage $L$. pholis leaves the pools that are shared by the juveniles of both species, seeking new shelters in crevices and spaces under boulders, in the lower shore, where they hide in groups (Qasim, 1957; Gibson, 1972; Faria and Almada, 2001). This shift in low-tide shelter is accompanied by a shift in diet, the larger $L$. pholis now eating larger prey (Monteiro et al., 2005).

Most studies on the ecology of these blennies have concentrated on observations made during low-tide, when their activity reached its minimum and fish congregate in shelters (e.g. Qasim, 1957; Gibson, 1972; Milton, 1983; Faria et al., 2001), so little consideration has been given to the possibility that partitioning of resources among the two species may occur through spatial and temporal differences in behaviour during high-tide. Burrows et al. (1999), using underwater TV observations, suggested that the shanny, Lipophrys pholis, shows the highest level of activity during the rising and high-tide periods, and that its feeding movements are concentrated around crevices. Faria and Almada (2006), based on 
visual underwater observations by snorkelling dives, described the patterns of space utilization by $L$. pholis and Coryphoblennius galerita, along the tidal cycle. Whereas $C$. galerita seems to keep an approximately constant position at a given shore level, probably in the vicinity of the shelters used during low-tide, L. pholis, especially the larger individuals, seems to move up and down with the tide, maximising submersion time.

This paper addresses the following question: Do the patterns of activity and vertical distribution of the two species along the tidal cycle reflect their different patterns of space and microhabitat use?

\section{Materials and methods}

The study period ranged from June 2005 to October 2005. The study site was a semi-exposed rocky platform, near the mouth of the Tagus river, Avencas $\left(38^{\circ} 41^{\prime} \mathrm{N}, 9^{\circ} 22^{\prime} \mathrm{W}\right)$.

The observations were based on visual censuses made by snorkelling dives. On each day, two dives were always performed (with a mean duration of $1 \mathrm{~h} 30 \mathrm{~min}$ to $2 \mathrm{~h}$ each), with intervals of 1-2 $\mathrm{h}$ between them, to cover two of the three distinct phases of the same tidal cycle: the rising phase (which corresponds to the submersion period that permits the diver to swim over the platform up to $1 \mathrm{~h}$ before high-tide); the high-tide phase (defined as the period $1 \mathrm{~h}$ before to $1 \mathrm{~h}$ after high-tide); and the ebbing phase (defined as the period from $1 \mathrm{~h}$ after high-tide to the time when water level no longer permitted the diver to swim over the platform).

In each dive two transects were inspected on two different rockwalls, almost parallel to the coast, that stay exposed during lowtide (see Faria and Almada, 2001 for habitat descriptions). A diver swam slowly and at a regular speed over each transect. Transects length was $70 \mathrm{~m}$ and $80 \mathrm{~m}$ and inspection of each took about 45-60 min to be completed.

For each dive, the species and size class, $<7 \mathrm{~cm}$ and $>7 \mathrm{~cm}$ for Lipophrys pholis, of each observed fish were recorded on an underwater writing pad. In addition, fish were classified as being feeding or not feeding, and either as active (when they were out of shelters) or inactive (when they were found in refuge). Both species fed by a very rapid action in which the fish turned its head to the prey and grasped it, followed by a strong jerking movement that pulled the food item from the rock. Size was visually estimated taking as a reference a ruler drawn in the writing pad. Separation of L. pholis in these two size classes was made because it is known that at this size a major ontogenetic shift in type of food consumed and kind of shelter used takes place in this species (Faria and Almada, 2001; Monteiro et al., 2005).

Additional dives were undertaken to perform focal observations (sensu Martin and Bateson, 1993), in which an individual fish was continually observed for 5 min or until the fish moved out of sight of the observer. For each fish, the behaviours exhibited and the distances travelled (estimated by eye) were recorded. A total of 47 fish were followed (30 Lipophrys pholis and 17 Coryphoblennius galerita). Although an eventual influence of the observer is almost impossible to disprove, the fact that the fish did not hide or escape and continued to feed actively, and move around, strongly suggests that they were not seriously affected by the presence of the diver.

A total of 40 dives were performed ( 10 during the rising-tide and 10 during the high-tide of the same day; 10 during the high-tide and 10 during the ebbing-tide of the same day). As this kind of dives was only possible when sea conditions were very favourable, the number of dives per month varied (June: 10 dives, July: 20 dives, October: 10 dives).

Statistical analysis involved two types of tests. Contingency tables were built for each species, and size class for Lipophrys pholis. In each table, the number of fish recorded as feeding and nonfeeding at each tidal phase (rising, high and ebbing-tide) was included. The contingency table analysis was performed using the program ACTUS (Estabrook and Estabrook, 1989), which implements a statistical simulation procedure designed to analyse contingency tables that is not limited by the assumptions of conventional Chi-Square Tests and that, apart from assessing the overall significance of the table, allows assessment of the significance of deviations of each individual cell. In addition, the numbers of fish of each species, and size class for L. pholis, observed feeding at each dive were analysed, as a function of the tidal phase, with a Kruskall-Wallis test, using the software Statistica 5.0 for Windows (Statsoft, 1995). As the overall result was significant, multiple comparisons were performed with Dunn test (Siegel, 1956).

\section{Results}

Both Lipophrys pholis and Coryphoblennius galerita were observed feeding on barnacles, limpets and algae (or organisms that grew on them). Lipophrys pholis was also observed feeding on mussels and small dead crabs. Normally individuals moved around a small area (L. pholis: average $=83.22 \mathrm{~cm}$, s.d. $=45.07$, range: $10-$ $500, n=30 ;$ C. galerita: average $=47.74 \mathrm{~cm}$, s.d. $=21.12$, average: $5-$ $150, n=17$ ), performing a series of small bites (L. pholis: average $=7.64$ per $5 \mathrm{~min}$., s.d. $=3.83$, range: $1-13 x, n=11 ; C$. galerita: average $=7.43$ per 5 min., s.d. $=6.55$, range: $1-22 x$, $n=14)$.

The number of active fish in the different tidal phases and the proportion of this number observed feeding are given in Table 1. Concerning feeding activity, in general a higher proportion of fish fed during the rising-tide (38\%) or the high-tide (56\%), than during the ebbing phase $(6 \%)$ (C. galerita: $\chi^{2}=15.01$, d.f. $=2, p<0.001$; Lipophrys pholis $(<7 \mathrm{~cm}) \chi^{2}=56.06$, d.f. $=2, p<0.001$; L. pholis $(>7 \mathrm{~cm}) \chi^{2}=17.06$, d.f. $\left.=2, p<0.001\right)$.

The number of fish observed on the rock-walls during the three different phases of the tidal cycle differed (Table 1 ). The number of Coryphoblennius galerita observed during the ebbing phase was smaller compared to the high-tide phase or the rising phase (Kruskall-Wallis test: $H(2, N=40)=22.632, p<0.001$; Dunn test: rising phase versus ebbing phase, $Q=4.256, p<0.001$; high-tide

Table 1

(Panel A) Number of fish observed in rock-walls during the tidal phases considered; (Panel B) proportion of fish observed feeding ( $n=$ number of days of observation)

\begin{tabular}{|c|c|c|c|c|c|c|c|c|c|}
\hline & \multicolumn{3}{|c|}{ Rising-tide $(n=10)$} & \multicolumn{3}{|l|}{ High-tide $(n=20)$} & \multicolumn{3}{|c|}{ Ebbing-tide $(n=10)$} \\
\hline & L. pholis $(<7 \mathrm{~cm})$ & L. pholis $(>7 \mathrm{~cm})$ & C. galerita & L. pholis $(<7 \mathrm{~cm})$ & L. pholis $(>7 \mathrm{~cm})$ & C. galerita & L. pholis $(<7 \mathrm{~cm})$ & L. pholis $(>7 \mathrm{~cm})$ & C. galerita \\
\hline \multicolumn{10}{|l|}{ Panel A } \\
\hline Mean & 51.70 & 26.20 & 39.10 & 39.10 & 31.65 & 35.95 & 49.60 & 74.80 & 7.50 \\
\hline s.d. & 11.02 & 7.86 & 3.54 & 16.08 & 18.29 & 9.19 & 31.86 & 32.26 & 1.35 \\
\hline Range & $25-61$ & $19-42$ & $32-45$ & $12-74$ & $9-75$ & $18-54$ & $12-103$ & $20-118$ & $5-9$ \\
\hline \multicolumn{10}{|l|}{ Panel B } \\
\hline Mean & 0.23 & 0.04 & 0.25 & 0.14 & 0.06 & 0.25 & 0.10 & 0.04 & 0.11 \\
\hline s.d. & 0.07 & 0.03 & 0.15 & 0.11 & 0.06 & 0.17 & 0.09 & 0.05 & 0.09 \\
\hline Range & $0.150-0.29$ & $0.00-0.05$ & $0.05-0.47$ & $0.05-0.47$ & $0.01-0.22$ & $0.07-0.44$ & $0.01-0.25$ & $0.01-0.17$ & $0.00-0.29$ \\
\hline
\end{tabular}


phase versus ebbing phase, $Q=4.169, p<0.001)$. On the contrary, the number of larger individuals of Lipophrys pholis $(>7 \mathrm{~cm})$ was higher in the rock-walls during the ebbing phase than in the preceding high-tide or rising phase (Kruskall-Wallis test: $H(2$, $N=40)=9.486, p<0.01$; Dunn test: rising phase versus ebbing phase, $Q=-2.668, p<0.01$; high-tide phase versus ebbing phase, $Q=-2.788, p<0.01)$. For small L. pholis $(<7 \mathrm{~cm})$ there were no statistical differences (Kruskall-Wallis test: $H(2, N=40)=4.682$, $p>0.05$ ).

\section{Discussion}

The results suggest that the patterns of activity observed in Lipophrys pholis and in Coryphoblennius galerita during the different tidal phases are probably related to feeding activities. Both species feed mainly on gastropods, barnacles and algae, with a minor proportion of other invertebrates like amphipods, copepods and isopods (Qasim, 1957; Gibson, 1972; Milton, 1983; Monteiro et al., 2005). As suggested by Burrows et al. (1999), these fish may be hungrier during the rising-tide, since in the previous tidal phase (low-tide) they have been confined to small refugia, like tide-pools and crevices, where the typical prey of both species (e.g. barnacles cirri, mussels) are usually unavailable (Gibson, 1972; Faria and Almada, 2001). Indeed, both barnacles and mussels tend to occur out of the pools, thus being available only when the rocks are covered by water. Our observations support this interpretation and show that the feeding patterns are especially intense during the rising-tide, when compared to the ebbing-tide. This means that the tidal variation of the feeding pattern is asymmetrical in nature. Similar evidence was provided by Ralston and Horn (1986) for Cebidichthys violaceus, a fish of a different taxonomic group (Stichaeidae). Apparently, pelagic fish that visit the intertidal during high-water to feed also show this asymmetry in the use of this area (e.g. Carlisle, 1961).

From a functional point of view, the pattern described in the present paper makes sense if one assumes that fish start feeding as soon as there is enough water, and that they also must be able to return to their low-tide shelter in time to avoid the risk of getting stranded in unsuitable locations. This hypothesis would explain why a fish ceases to feed and begins to seek shelter while there is still enough water to move around.

This interpretation is also consistent with the differences observed between Coryphoblennius galerita and small Lipophrys pholis on one hand and larger L. pholis on the other. As shown by Faria and Almada (2001, 2006), both C. galerita and small L. pholis feed on the rock-platforms which are typically in the vicinity of the tide-pools where they shelter during low-tide. On the contrary, $L$. pholis larger than $7-8 \mathrm{~cm}$, move up and down with the tide, and spend the low-tide time in crevices often located in the lower shore. This would explain why their relative abundance on the rock-wall increased at the beginning of the ebbing-tide, as we were likely observing fish that had moved to the highest levels of the platform and were in their downward movements as the tide ebbed. This increase could also occur if part of the population migrated to the subtidal. In that case, we would be observing the congregation of fish coming both from above and below. This possibility is however, very unlikely, as very few L. pholis occur sub tidally in any tidal phase (Faria and Almada, 2006).

One limitation of our observations stems from the fact that they were made from June to October. It would be interesting to study the behaviour of this fish in winter, when sea conditions and the entire ecology of the intertidal are radically altered. However, in this area of the Atlantic, winter conditions make regular dives very hard to achieve. The same applies to very exposed shores, where the behaviour of intertidal fish during high-tide is virtually unknown. This work emphasizes the need of more field studies that cover the entire tidal cycle to get a full understanding of the ecology of intertidal fish assemblages.

\section{Acknowledgments}

Part of this study was supported by Fundação para a Ciência e Tecnologia (FCT) within the Plurianual Program (UI\&D 331/94, partially FEDER funded) and by FCT and FEDER within the project POCTI/BSE/46825/2002. C.F. was also supported by a grant from FCT (SFRH/BPD/14478/2003). We thank C. Luís and C. Silva who helped with the field work.

\section{References}

Bhikajee, M., Green, J.M., 2002. Behaviour and habitat of the Indian Ocean amphibious blenny, Alticus monochrus. African Zoology 37, 221-230.

Burrows, M.T. Kawai, K. Hughes, R.N., 1999. Foraging by mobile predators on a rocky shore: underwater TV observations of movements of blennies Lipophrys pholis and crabs Carcinus maenas. Marine Ecology Progress Series 187, 237-250.

Carlisle, D.B., 1961. Intertidal territory in fish. Animal Behaviour 9, 106-107.

Estabrook, C.B., Estabrook, G.F., 1989. ACTUS: a solution to the problem of small samples in the analysis of two-way contingency tables. Historical Methods 22 $5-8$.

Faria, C., Almada, V., 1999. Variation and resilience of rocky intertidal fish in western Portugal. Marine Ecology Progress Series 184, 197-203.

Faria, C., Almada, V., 2001. Microhabitat segregation in three rocky intertidal fish species in Portugal: does it reflect interspecific competition? Journal of Fish Biology 58, 145-159.

Faria, C., Almada, V.C., 2006. Patterns of spatial distribution and behaviour of fish on a rocky intertidal platform at high tide. Marine Ecology Progress Series 316 $155-164$.

Faria, C., Almada, V.C., Gonçalves, E.J., 1996. Juvenile recruitment, growth and maturation of Lipophrys pholis (Pisces: Blenniidae), from the west coast of Portugal. Journal of Fish Biology 49, 727-730.

Gibson, R.N., 1967. Experiments on the tidal rhythm of Blennius pholis. Journal of Marine Biological Association of the United Kingdom 47, 97-111.

Gibson, R.N., 1970. The tidal rhythm of activity of Coryphoblennius galerita (L.) (Teleostei, Blenniidae). Animal Behaviour 18, 529-543.

Gibson, R.N., 1972. The vertical distribution and feeding relationships of intertidal fish on the Atlantic cost of France. Journal of Animal Ecology 41, 189-207.

Gibson, R.N., 1973. The intertidal movements and distribution of young fish on a sandy beach with special reference to the plaice (Pleuronectes platessa L.) Journal of Experimental Marine Biology and Ecology 12, 79-102.

Gibson, R.N., 1982. Recent studies on the biology of intertidal fishes. Oceanographic and Marine Biology, Annual Review 20, 363-414.

Gibson, R.N., 1999. Movement and homing in intertidal fishes. In: Horn, M.H., Martin, K.L.M., Chotkowski, M.A. (Eds.), Intertidal Fishes: Life in Two Worlds Academic Press, San Diego, pp. 97-125.

Martin, P., Bateson, P., 1993. Measuring Behaviour, second ed. Cambridge University Press, Cambridge, $200 \mathrm{pp}$.

Milton, P., 1983. Biology of littoral blenniid fishes of the coast of south-west England. Journal of Marine Biological Association of the United Kingdom 63 223-237.

Monteiro, N.M., Quinteira, S.M., Silva, K., Vieira, M.N., Almada, V.C., 2005. Diet preference reflects the ontogenetic shift in microhabitat use in Lipophrys pholis. Journal of Fish Biology 67, 102-113.

Northcott, S.J., 1991. A comparison of circatidal rhythmicity and entrainment by hydrostatic pressure cycles in the rock goby, Gobius paganellus L. and the shanny, Lipophrys pholis L. Journal of Fish Biology 39, 25-33.

Northcott, S.J., Gibson, R.N., Morgan, E., 1990. The persistence and modulation of endogenous circatidal rhythmicity in Lipophrys pholis (Teleostei). Journal of Marine Biological Association of the United Kingdom 70, 815-827.

O'Farrell, M.M., Fives, J.M., 1990. The feeding relationship of the shany, Lipophrys pholis (L.) and Montagu's blenny, Coryphoblennius galerita (L.) (Teleostei: Blenniidae). Irish Fisheries Investigations (Series B) 36, 3-16.

Qasim, S.Z., 1957. The biology of Blennius pholis L. (Teleostei). Proceedings of the Royal Society of London 128, 161-208.

Ralston, S.L., Horn, M.H., 1986. High tide movements of the temperate-zone herbivorous fish Cebidichthys violaceus (Girard) as determined by ultrasonic telemetry. Journal of Experimental Marine Biology and Ecology 98, 35-50.

Siegel, S., 1956. Non-parametric Statistics for the Behavioural Science. McGraw-Hill, New York, 312 pp.

Williams, B.G., Naylor, E., 1969. Synchronization of the locomotor tidal rhythm of Carcinus. Journal of Experimental Biology 51, 715-725.

Zander, C.D., 1986. Blenniidae. In: Whitehead, P.J.P., Bauchot, M.-L., Hureau, J.-C., Nielsen, J., Tortonese, E. (Eds.), Fishes of the North-Eastern Atlantic and the Mediterranean. UNESCO, Paris, pp. 1096-1112. 